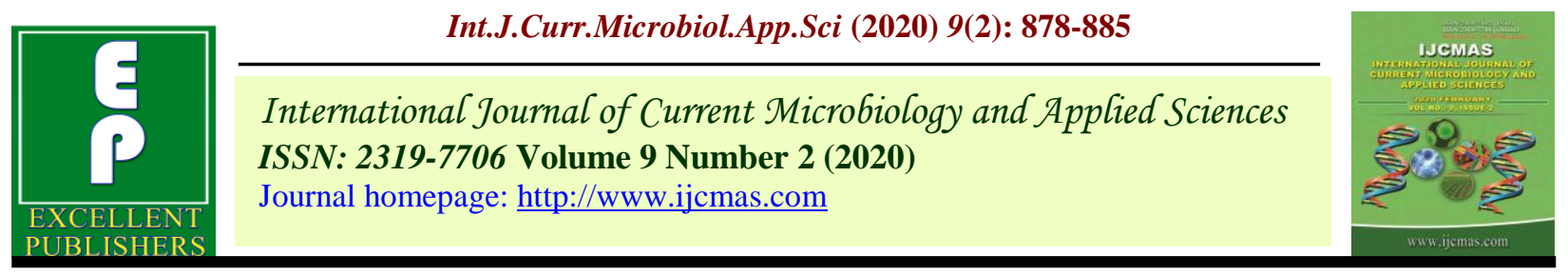

Original Research Article

https://doi.org/10.20546/ijcmas.2020.902.105

\title{
Growth and Yield of Rabi Season Forage Crops under Chhattisgarh Plain of Madhya Pradesh, India
}

\author{
A.K. Shrivastava ${ }^{1 *}$, S. Sarvade ${ }^{1}$, N.K. Bisen ${ }^{1}$, Brajkishor Prajapati ${ }^{2}$, \\ S.B. Agrawal ${ }^{1}$ and Pooja Goswami ${ }^{1}$ \\ College of Agriculture, Balaghat-481331, JNKVV, Jabalpur (MP) \\ KVK, Badgaon, JNKVV, Jabalpur (MP), India \\ *Corresponding author
}

\section{Keywords}

Crude protein content, dry matter content, digestible dry matter content, green fodder yield

Article Info

Accepted:

08 January 2020

Available Online:

10 February 2020

\section{A B S T R A C T}

The experiment was conducted during rabi season of 2017-18 at experimental block of Murjhad farm, College of Agriculture, Balaghat, Madhya Pradesh, India to evaluate yield and quality parameters of rabi season forage crops. The treatments consisted of four crops i.e. sole oat, sole makkhan grass, sole local rye and sole berseem in a randomized block design with seven replications. The analysis of data indicated that dry matter content, green fodder yield, dry fodder yield and digestible dry matter yield were highest in case of makkhan grass over other crops. At 3rd cutting, makkhan grass yielded significantly more green fodder yield compared to berseem and oat. The total dry fodder yield of makkhan grass was significantly increased by $33.35,7.38$ and 7.77 per cent, respectively over berssem, oat and local rye grass. Whereas, crude protein content, dry matter digestibility and crude protein yield was highest in berseem than other crops. Crude protein yield was increased $19.53,52.23$ and 28.71 per cent at $3^{\text {rd }}$ cutting and $15.32,50.54$ and 24.19 per cent at $4^{\text {th }}$ cutting in berseem crop over makkhan grass, oat and local rye grass, respectively. At $2^{\text {nd }}, 3^{\text {rd }}$ and $4^{\text {th }}$ cuttings, digestible dry matter yield from makkhan grass was significantly higher than other crops.

\section{Introduction}

Animal husbandry is a backbone of farming communities, which contributes about 4.5 per cent to National GDP and shares about 15-20 per cent to the total income of rural households. The livestock population of our country is expected to grow at the rate of 0.55 per cent and likely to reach around 781 million by 2050 (Ghosh e al., 2016).

Indian dairy sector is estimated to contribute around 18.5 per cent of world total milk production from 512.1 million livestock (Sarvade and Upadhyay, 2019) with annual growth rate around 4.1 per cent. 
The productivity of Indian livestock is very low is associated with the availability of good quality and quantity of fodder. It has been considered as the major bottleneck in harnessing the potential of the livestock (Palsaniya $e$ al., 2011 and Sarvade $e$ al., 2019). At present, the country faces a net deficit of 63 per cent green fodder, 24 per cent dry fodder and 64 per cent feeds, respectively (Choudhary e al., 2014).

Country to this fact, the area under permanent pastures has been declining over the years and uncontrolled overgrazing grazing has made them less productive. In order to meet the fodder shortage for the growing animal population, the fodder growing area should ideally be around 12.0 million ha well distributed in different season to make round the year availability of fodder (Prajapati $e a l$., 2016).

The yielding potential of local rabi season forage crops is declining day by day due to abiotic and biotic stresses. In order to overcome this problem new rabi season forage crops need to be tested and introduced. In view, present study was conducted to evaluate the key forage crop for rabi season in Chhattisgarh plain area.

\section{Materials and Methods}

The study was conducted during rabi season of 2017-18 at experimental block of Murjhad farm, College of Agriculture, Balaghat, Madhya Pradesh, India. The Farm is situated in the Chhattisgarh Platue with sub-tropical type of climate at latitude of $21.4^{\circ} \mathrm{N}$ and longitude of $80.3^{\circ} \mathrm{E}$ and situated at an altitude of $303 \mathrm{~m}$ above the mean sea level. The soil of experimental site is clay loam with neutral reaction $(7.1 \mathrm{pH})$.

Nutritional status of the soil was medium in organic carbon $(0.50 \%)$, available nitrogen
(210.4 kg/ha), available phosphorus (13.8 $\mathrm{kg} / \mathrm{ha}$ ) and available potassium (198 kg/ha) obtained by following Walkley and Black, 1934, Subbiah and Asija, 1956, Olsen e al., 1954 and Jackson, 1973, respectively. The experiment was laid out in randomized block design with seven replications and comprising four treatments i.e. sole local ryegrass, sole oat, sole makkhan grass and sole berseem. Oat $(100$

$\mathrm{kg} / \mathrm{ha}$ seed), local rye grass and makkhan grass (15 kg/ha seed), berseem (30kg/ ha seed) at $25 \mathrm{~cm}$ row to row spacing were sown in $3 \mathrm{~cm}$ deep furrows opened with the help of hand hoe. Half quantity of the total dose of nitrogen through urea @ $120 \mathrm{~kg}$ N/ha (grasses), $25 \mathrm{~kg} \mathrm{~N} / \mathrm{ha}$ (legumes), $60 \mathrm{~kg}$ $\mathrm{P}_{2} \mathrm{O}_{5} /$ ha through single super phosphate and $40 \mathrm{~kg} \mathrm{~K} \mathrm{~K}_{2} \mathrm{O} / \mathrm{ha}$ through muriate of potass as basal were applied uniformly. Rest 50 per cent nitrogen was top dressed at $2^{\text {nd }}$ and $3^{\text {rd }}$ cuttings.

The crops were harvested at 55 days after sowing (first cut) with the help of sickle leaving stubble height of 5-6 cm from ground for uniform and quick regrowth. Subsequent cuttings were taken 30 days after each cutting till crops stop to re-growth. The harvested herbage was weighted immediately for green forage yield and $500 \mathrm{~g}$ fresh sample from each net plot $(1 \mathrm{~m} \times 1 \mathrm{~m})$ was taken to determine dry matter content. The samples were dried at $70^{\circ} \mathrm{C} \pm 2$ in hot air oven for moisture loss.

The finely grinded dry samples using $2 \mathrm{~mm}$ sieve were used for nitrogen content by Micro kjeldahl method (Jackson, 1973). The crude protein content was determined by multiplying nitrogen per cent with 6.25 (AOAC, 1965) and digestible dry matter content by the nylon bag method (Mehrez and Orskov, 1977). The data was subjected to analysis of variance (ANOVA) technique 
using the statistical programme OPSTAT (www.hau.ernet.in/opstat.html) to draw inference of the results. Valid conclusions were drawn only on significant differences between treatment means at 5\% level of probability.

\section{Results and Discussion}

\section{Growth parameters}

Plants of oat were significantly taller as compared to other crops at $1^{\text {st }}$ and $2^{\text {nd }}$ cuttings. It may be due to genetic makeup compared to other crops (Joshi e al., 2000). At $3^{\text {rd }}$ cutting, height of makkhan grass plants were significantly taller than remaining crops except local rye grass, while at $4^{\text {th }}$ cutting these plants were statistically at par with oat and local rye grass.

The increased in plants height of makkhan grass was $22.59,11.19$ and 6.87 per cent over berseem oat and local rye grass, respectively. Least plant height was observed in the case of berseem at all the cuttings. At $1^{\text {st }}, 3^{\text {rd }}$ and $4^{\text {th }}$ cuttings, tillers of makkhan grass were significantly higher compared to oat and local rye grass, while at $2^{\text {nd }}$ cutting, these differences disappeared. Similar results were also reported by Prajapati $e$ al., (2016).

At $1^{\text {st }}$ and $2^{\text {nd }}$ cuttings, number of leaves of makkhan grass were significantly higher compared to other crops except local rye grass while $3^{\text {rd }}$ and $4^{\text {th }}$ cutting, it was at par with oat and local rye grass.

\section{Quality}

\section{Dry matter content}

At $1^{\text {st }}$ cutting, dry matter content of oat was significantly higher over berseem crop and at par with makkhan grass and local rye grass. Increased dry matter content of oat might be due to taller plants. At $2^{\text {nd }}$ cutting similar dry matter content obtained from makkhan grass and oat, while it was statistically at par with local rye grass. At $4^{\text {th }}$ cutting, dry matter content of makkhan grass was significantly higher over berseem.

The capacity of plant to accumulate dry matter is determined by its rate of $\mathrm{CO}_{2}$ fixation, photosynthetic area, duration of crop, tillers/plant and environmental factor besides management practices (Jasjeet $e$ al., 2011). At $3^{\text {rd }}$ cutting, these differences disappeared. At all the cuttings, least dry matter content was observed for berseem crop. It might be due to smaller plants height, less tillers/plant and number of leaves in berseem crop (Table 1). Increased in dry matter content was $17.85,11.59$ and 12.88 per cent for makkhan grass over berseem at $1^{\text {st }}$, $2^{\text {nd }}$ and $4^{\text {th }}$ cuttings, respectively.

\section{Crude protein content}

In general, crude protein content at each cutting exhibited decreasing trend with the advancing of crop to maturity. At all cuttings, higher crude protein was observed in fodder of berseem crop, which was significantly higher over remaining crops and least crude protein content was obtained in fodder of oat crop. Crude protein content was increased 38.33. 47.50 and 38.75 per cent by berseem over makkhan grass, oat and local rye grass, respectively at $1^{\text {st }}$ cutting. Better absorption of nitrogen by deep-rooted berseem crop resulted for higher crude protein content. The results are conformity with the finding of Prajapati e al., (2016) and Tiwana and Puri (2003).

\section{Digestible dry matter content}

In general, the decline in dry matter digestibility is associated with increasing cell wall contents and it simply act as physical 
barrier to microbial enzymes (Prajapati $e$ al., 2017).

At all the cuttings, highly digestible dry matter content was observed in fodder of berseem crop, which was significantly higher over remaining crops. This is might be due to lower dry matter content and higher the value of crude protein at all the cuttings (Table 1).

Results of earlier workers suggest that negative correlation exists between dry matter and digestible dry matter content and positive association with crude protein content (Tiwari e al., 2019 and Beck e al., 2007).

The increased in digestibility of dry matter content was 3.66, 7.34 and 5.42 per cent for berseem crop over makkhan grass, oat and local rye grass, respectively at $4^{\text {th }}$ cutting.

\section{Yield}

\section{Green fodder yield}

Total green fodder yield was significantly more in the case of makkhan grass as compared to other crops except oat. It also increased total green fodder yield by 24.86 and 6.11 per cent over berseem and local rye grass.

At $1^{\text {st }}$ cutting green fodder yield of oat crop was significantly higher over remaining crops. The green fodder was increased 46.20, 56.43 and 52.40 per cent over makkhan grass, berseem and local rye grass, respectively. At $2^{\text {nd }}$ cutting, oat crop yielded highest green fodder yield and it was significantly higher over berseem.

At $3^{\text {rd }}$ cutting, makkhan grass yielded significantly more green fodder yield compared to berseem and berseem and oat at $4^{\text {th }}$ cutting. It might be due to taller plants height, more tillers/plant, more number of leaves and higher dry matter accumulation by crop (Table 1).

\section{Dry fodder yield}

The total dry fodder yield of makkhan grass was significantly higher than other crops. It also increased total dry fodders yield by $33.35,7.38$ and 7.77 per cent, respectively over berssem, oat and local rye grass.

At $1^{\text {st }}$ cutting, dry fodder yield obtained from oat crop was significantly more compared to other crops and it was significantly higher over berseem crop at $2^{\text {nd }}$ cutting. At $3^{\text {rd }}$ and $4^{\text {th }}$ cuttings, dry fodder yield of makhhan grass was significantly higher over berseem and oat, while it was statistically at par with local rye grass.

\section{Crude protein yield}

Total crude protein yield obtained from berseem crop was significantly higher over remaining crops. It might be due to highest dry matter production and crude protein content because crude protein yield is function of crude protein content and dry matter yield. Similar results were also reported by Joshi e al., (2012).

At $1^{\text {st }}$ cutting, crude protein yield of oat was significantly higher over remaining crops, while at $2^{\text {nd }}$ cutting, highest crude protein yield obtained from makkhan grass as compared to other crops.

At $3^{\text {rd }}$ and $4^{\text {th }}$ cuttings, crude protein yield from berseem crop was significantly higher than remaining crops. Crude protein yield was increased $19.53,52.23$ and 28.71 per cent at $3^{\text {rd }}$ cutting and 15.32, 50.54 and 24.19 per cent at $4^{\text {th }}$ cutting by berseem crop over makkhan grass, oat and local rye grass, respectively. 
Int.J.Curr.Microbiol.App.Sci (2020) 9(2): 878-885

Table.1 Growth parameters and quality parameters of different crops at different cuttings

\begin{tabular}{|c|c|c|c|c|c|c|c|c|}
\hline \multirow[t]{3}{*}{ Treatments } & \multicolumn{4}{|c|}{ Plant height (cm/plant) } & \multicolumn{4}{|c|}{ Number of tillers/plant } \\
\hline & \multicolumn{8}{|c|}{ Cutting } \\
\hline & 1 & 2 & 3 & 4 & 1 & 2 & 3 & 4 \\
\hline Makkhan Grass & 39.50 & 48.23 & 69.97 & 65.96 & 8.00 & 8.86 & 13.00 & 12.90 \\
\hline Berseem & 27.50 & 36.80 & 42.30 & 51.06 & 4.00 & 6.86 & 8.67 & 8.30 \\
\hline Oat & 51.06 & 56.10 & 62.24 & 58.58 & 5.00 & 7.64 & 10.41 & 8.54 \\
\hline Local Rye Grass & 36.98 & 44.53 & 67.83 & 61.43 & 7.43 & 8.29 & 10.71 & 9.69 \\
\hline SEm \pm & 1.83 & 1.89 & 2.18 & 2.73 & 0.35 & 0.69 & 0.52 & 0.65 \\
\hline \multirow[t]{2}{*}{ CD at $5 \%$} & 5.48 & 5.67 & 6.54 & 8.17 & 1.04 & NS & 1.55 & 1.96 \\
\hline & \multicolumn{4}{|c|}{ No. of leaves/m row length } & \multicolumn{4}{|c|}{ Dry matter content } \\
\hline Makkhan grass & 341.46 & 360.48 & 719.76 & 667.38 & 12.49 & 13.80 & 14.54 & 15.61 \\
\hline Berseem & 194.29 & 264.76 & 533.33 & 476.19 & 10.26 & 12.20 & 13.39 & 13.60 \\
\hline Oat & 216.51 & 304.29 & 651.90 & 626.67 & 13.57 & 13.80 & 13.28 & 14.29 \\
\hline Local Rye Grass & 321.57 & 335.71 & 690.24 & 638.19 & 12.17 & 13.63 & 14.21 & 15.33 \\
\hline SEm \pm & 12.33 & 14.02 & 26.13 & 22.68 & 0.50 & 0.33 & 0.56 & 0.45 \\
\hline \multirow[t]{2}{*}{ CD at $5 \%$} & 36.92 & 41.97 & 78.24 & 67.92 & 1.48 & 1.01 & NS & 1.33 \\
\hline & \multicolumn{4}{|c|}{ Crude protein content (\%) } & \multicolumn{4}{|c|}{ Digestible dry matter content (\%) } \\
\hline Makkhan grass & 14.80 & 13.50 & 12.70 & 11.40 & 64.50 & 64.10 & 62.80 & 60.40 \\
\hline Berseem & 24.00 & 22.90 & 21.30 & 19.10 & 66.70 & 65.80 & 64.30 & 62.70 \\
\hline Oat & 12.60 & 10.60 & 9.50 & 8.40 & 62.80 & 60.20 & 59.80 & 58.10 \\
\hline Local Rye Grass & 14.70 & 13.20 & 12.00 & 11.10 & 63.40 & 62.90 & 60.60 & 59.30 \\
\hline SEm \pm & 0.40 & 0.42 & 0.25 & 0.24 & 0.36 & 0.47 & 0.37 & 0.30 \\
\hline CD at 5\% & 1.31 & 1.35 & 0.80 & 0.79 & 1.17 & 1.52 & 1.21 & 0.99 \\
\hline
\end{tabular}


Table.2 Yields of different crops at different cuttings

\begin{tabular}{|c|c|c|c|c|c|}
\hline \multirow[t]{3}{*}{ Treatments } & \multicolumn{4}{|c|}{ Green fodder yield (q/ha) } & \multirow[t]{2}{*}{ Total } \\
\hline & \multicolumn{4}{|c|}{ Cutting } & \\
\hline & 1 & 2 & 3 & 4 & \\
\hline Makkhan Grass & 34.70 & 148.30 & 184.80 & 177.20 & 545.00 \\
\hline Berseem & 28.10 & 87.50 & 149.70 & 144.20 & 409.50 \\
\hline Oat & 64.50 & 155.80 & 161.40 & 153.40 & 535.10 \\
\hline Local Rye Grass & 30.70 & 137.80 & 177.50 & 165.70 & 511.70 \\
\hline SEm \pm & 2.76 & 6.42 & 5.08 & 5.42 & 7.78 \\
\hline \multirow[t]{2}{*}{ CD at $5 \%$} & 8.27 & 19.43 & 15.2 & 16.38 & 25.23 \\
\hline & \multicolumn{4}{|c|}{ Dry fodder yield (q/ha) } & \\
\hline Makkhan grass & 4.35 & 20.53 & 26.89 & 27.66 & 79.43 \\
\hline Berseem & 2.87 & 10.67 & 19.93 & 19.47 & 52.94 \\
\hline Oat & 8.80 & 21.43 & 21.41 & 21.93 & 73.57 \\
\hline Local Rye Grass & 3.72 & 18.83 & 25.26 & 25.45 & 73.26 \\
\hline SEm \pm & 0.37 & 1.01 & 1.26 & 1.10 & 1.34 \\
\hline \multirow[t]{2}{*}{ CD at $5 \%$} & 1.12 & 3.02 & 3.78 & 3.31 & 4.33 \\
\hline & \multicolumn{4}{|c|}{ Crude protein yield (q/ha) } & \\
\hline Makkhan grass & 0.64 & 2.77 & 3.42 & 3.15 & 9.98 \\
\hline Berseem & 0.69 & 2.44 & 4.25 & 3.72 & 11.10 \\
\hline Oat & 1.11 & 2.27 & 2.03 & 1.84 & 7.25 \\
\hline Local Rye Grass & 0.55 & 2.49 & 3.03 & 2.82 & 8.89 \\
\hline SEm \pm & 0.02 & 0.02 & 0.03 & 0.06 & 0.21 \\
\hline \multirow[t]{2}{*}{ CD at $5 \%$} & 0.06 & 0.06 & 0.09 & 0.19 & 0.68 \\
\hline & \multicolumn{4}{|c|}{ Digestible dry matter yield (q/ha) } & \\
\hline Makkhan grass & 2.81 & 13.16 & 16.89 & 16.71 & 49.57 \\
\hline Berseem & 1.91 & 7.02 & 12.81 & 12.21 & 33.95 \\
\hline Oat & 5.53 & 12.90 & 12.80 & 12.74 & 43.97 \\
\hline Local Rye Grass & 2.36 & 11.84 & 15.31 & 15.09 & 44.6 \\
\hline SEm \pm & $\mathbf{0 . 0 3}$ & 0.02 & 0.02 & 0.02 & 0.57 \\
\hline CD at $5 \%$ & 0.09 & 0.08 & 0.06 & 0.07 & 1.84 \\
\hline
\end{tabular}




\section{Digestible dry matter yield}

The total digestible dry matter yield of makkhan grass was significantly higher than other crops. The increased in total digestible dry matter yield was 31.51, 11.29 and 10.03 per cent by makkhan grass over berseem, oat and local rye grass, respectively. It is because of higher dry matter yield and digestibility. Since the digestible dry matter yield is a function of dry matter digestibility and dry matter yield, the crops having higher values of this parameter out yielded digestible dry matter yield over other crops.

At $1^{\text {st }}$ cutting, oat crop yielded significantly higher digestible dry matter yield as compared to other crops. At $2^{\text {nd }}, 3^{\text {rd }}$ and $4^{\text {th }}$ cuttings, digestible dry matter yield from makkhan grass was significantly higher than other crops.

Based on the present investigation, it is concluded that crude protein content, dry matter digestibility and crude protein yield was higher in berseem than other crops.

Growth parameters, dry matter content, green fodder yield, dry fodder yield, crude protein yield and digestible dry matter yield were more of makkhan grass over other crops.

\section{Acknowledgement}

Authors are thankful to Dean, College of Agriculture, Balaghat and ADVANTA, for supplying planting materials, guidance, encouragement and providing necessary facilities during the period of study.

\section{References}

AOAC 1965. Official methods of analysis. $10^{\text {th }}$ ed. Association of official Agricultural Chemicals. Washington, DC, USA.
Beck JJ, Kim JH, Campbell BC and Chou SC. 2007. Fungicidal activities of dihydroferulic acid alkyl ester analogues. J Nat Prod. 70(5):779-82.

Chaudhary D.P., Jat S.L., Kumar R., Kumar A., and Kumar B. 2014. Fodder quality of maize: Its preservation. In: D.P. Chaudhary $e$ al., (eds.), Maize: Nutrition Dynamics and Novel Uses. Springer. 153- 160.

Ghosh P K, Palsaniya D R and Srinivasan R. 2016. Forage research in India: issues and strategies. Agric Res J. 53 (1): 1-12. Jackson, M.L. 1973. Soil chemical analysis constable and Co. Ltd. Prentice Hall of India Pvt. Ltd New Delhi.

Jasjeet, D., Pankaj, K., Tiwari, B.N. and P. Rakesh, 2011. Chemo- pharmacological aspects of alfalfa: A Review. Journal of Advanced Scientific Research, 2: 50-53.

Joshi, Y.P., Kumar, S. and Faruqui, S.A. 2012. Production potential and economic feasibility of year round forage production system in Tarai region of Uttarakhand. Range management and Agroforestry. 33(1): 65-68.

Joshi, Y.P., Singh, V.S. Verma, S. and C.S. Pandey, 2000. Effect of cutting management on on herbages and seed yield on oat genotypes. J. Farming System Res. \& Dev., 6: 74 -78.

Mehrez, A.Z. and E.R. Ovaskor, 1977. A study on the artificial fibre bag Technique for determining the digestibility of feeds in the rumen. $J$. Agric. Sci. Combr., 88: 645-650.

Palsaniya DR, Dhyani SK and RaiP 2011b. Silvipasture in India:Present Perspectives and Challenges Ahead. Scientific Publishers, Jodhpur, India, pp. 207.

Prajapati, B., Bhatnagar, A. and Kewalanand, 2017. Quality analysis of winter season forage crops. Forage Research. 42(4): 252-257. 
Prajapati, B., Bhatnagar, A. and Kewalanand, 2016. Growth and yield of cool season forage crops under tarai reagion of Uttarakhand. Forage Research, 42(2) : 101-108.

Olsen, S.R., Cole, C.V., Watanabe, F.S. and Dean, L.A. 1954. Estimation of available phosphorus in soils by extraction with sodium bicarbonate. USDA. Circular. Govt printing office Washington D. C. 939: 1-19.

Sarvade, S. and Upadhyay, V.B. 2019. Silvopasture system: a way ahead for sustainable development in India. In: Agroforestry and Climate Change: Issues and Challenges. Ed(s): Manoj Kumar Jhariya, Dhiraj Kumar Yadav, Arnab Banerjee. CRC Press, New York. PP-155-188.

Sarvade, S, Upadhyay, V.B. and Agrawal, S.B. 2019. Quality fodder production through silvo-pastoral system: a review.
In: Agroforestry for Climate Resilience and Rural Livelihood, Eds: Inder Dev, Asha Ram, Naresh Kumar, Ramesh Singh, Dhiraj Kumar, A.R. Uthappa, A.K. Handa and O.P. Chaturvedi. Scientific Publishers. Jodhpur (Raj.). PP- 345- 359.

Subbiah, B.V. and Asija, H.L. 1956. A rapid procedure for estimation of the available nitrogen in soils. Current Science. 25: 259-260.

Tiwari, S., Prajapati, B. and Kewalanand, 2019. Correlation Studies of Quality Traits and Yields of Fodder Obtained from Intercropping Systems under Tarai Region of Uttarakhand, India. Int.J.Curr.Microbiol.App.Sci., $\quad 8(10)$ : 997-1002.

Tiwana U.S. and Puri, K.P. 2003. Response of berseem to Sulphur under different fertilizer levels. Forage Res., 29: 94-96.

\section{How to cite this article:}

Shrivastava. A.K., S. Sarvade, N.K. Bisen, Brajkishor Prajapati, S.B. Agrawal and Pooja Goswami. 2020. Growth and Yield of Rabi Season Forage Crops under Chhattisgarh Plain of Madhya Pradesh. Int.J.Curr.Microbiol.App.Sci. 9(02): 878-885. doi: https://doi.org/10.20546/ijcmas.2020.902.105 